\title{
The empathic subject and the question of dividuality
}

\section{Introduction}

Emotions and their history have recently become the subject of intense inquiry and research. Studies try to trace the role of emotions in philosophy, theatre, literature, social and cognitive sciences from a historical perspective. The focus hereby lies on the Western hemisphere and on the modern period (18th century until present). ${ }^{1}$

In her study of the history of concepts and debates on emotions since 1700, Ute Frevert asks about the relationship between individualisation - understood as progressive emancipation of the individual from religious, social and occupational bonds and commitments - and the discussion of the nature of emotions (Frevert 2014, 5f.). She argues that emotions or feelings document a specific quality of the individual and therefore are assigned a special dignity and value in modern society. Emotions connect human beings to one another, but also to nature and to objects. Frevert strongly highlights the social role of emotions: grounded in reciprocity, they facilitate social bonding and further social integration among human beings.

Taken to its logical end, Frevert's statement of the social quality of emotions allows drawing the conclusion that emotions might influence processes of individualisation in such ways that they probably counteract (mitigate, weaken) individual attempts of disentanglement, of creating impermeable boundaries between oneself and the outer as well as social world. Or, reformulating the argument in the form of a question and with reference to Charles Taylor (2007): do we have to take emotions into consideration when we ask about the relationship between a 'porous' and 'vulnerable' Self and a 'buffered' or 'bounded' Self?

In this contribution I am not going to look into particular emotions; my purpose is rather to focus on empathy, often described as emotional competence or emotional intelligence and referring to the capability of a person to experience and understand other people's sentiments. According to recent neuro-scientific

1 In Germany research is concentrated at the 'Center for the History of Emotions', which is part of the Max Planck Institute for Human Development, Berlin; geographically the Center focuses on Europe, North America and South Asia. For a historical account of research on emotions in Europe in the last three centuries see Frevert et al. 2014. See also Landweer, Renz 2008.

2 Open Access. (c) 2019 Antje Linkenbach, published by De Gruyter. (ल) BY-NC-ND This work is licensed under a Creative Commons Attribution-NonCommercial-NoDerivatives 4.0 International License. https://doi.org/10.1515/9783110580853-018 
and philosophical research, empathy has an emotional and a cognitive dimension. Empathy 'can be defined as a multidimensional process of recognising, understanding and feeling the sentiments of other persons and thus includes cognitive (recognition and understanding) as well as emotional (feeling) aspects' (Schwenck et al. 2011, 265; transl. AL). ${ }^{2}$

Similarly to the interest in emotions, the notion and concept of empathy has gained scholarly attention across disciplines and the rise of its significance in European intellectual history, literature and public discourse since the 17th century has been well documented. Such increased attentiveness may indicate that empathy, by revealing the relationality and sociality of human beings, might also act as an obstacle to radical individualisation, based on the imaginary of a detached and self-contained individual. In other words and using another concept: empathy possibly triggers and supports dividualisation ${ }^{3}$; it possibly indicates that individuals are partible and porous instead of bounded, that they are permeated, deeply affected and marked by the outside world - and the outside world consists of fellow beings, objects and 'not unquestionably plausible' agents or authorities as for example the transcendent, the divine (Rüpke 2015).

This article will discuss empathy in its particular manifestation of co-feeling with the pain and suffering of fellow beings. The text is organised into six sections. In the first section and as a starting point I present core ideas of the 'anthropology of violence' in order to show that in the context of human suffering empathy is closely linked to ideas of the communicability of pain, of healing and morality. Pursuing a socio-historical perspective, section 2 aims to illustrate the historical shift from a theological to a secular understanding of suffering which also, on the one hand, gave rise to individualisation, and on the other to an increased importance of morality and sociality understood as a result of human praxis. The next three sections focus on conceptual approaches: section 3 traces the conceptual forerunners of empathy and discusses 'sympathy' and 'imagination' in the intellectual landscape of the 17th and 18th centuries, followed by (in section 4) reflections on the relationship between empathy, language and understanding as

2 German original: Empathie 'kann definiert werden als ein multidimensionaler Prozess des Erkennens, Verstehens und Nachempfindens der Gefühle anderer Personen und beinhaltet damit sowohl kognitive (Erkennen und Verstehen) als auch emotionale (Nachempfinden) Aspekte' (Schwenck et al. 2011, 265).

3 For the concept of dividualisation see the introduction to Part 2 of this publication and the concluding discussion of this article. For now it is sufficient to recollect that for the purposes of this article (as well as for the purposes of all other contributions to Part 2) dividualisation is not used in the strict sense as it is defined in New Melanesian Ethnography, but as an umbrella term which can encompass all those forms of the individual that do not subscribe to the bounded possessive individual of the Western discourse. 
a cornerstone for a desirable moral and social life; this section also touches upon the difference between empathic identification and unification (assimilation). Part 5 refers to contemporary approaches to empathy (neurosciences, phenomenological philosophy). Especially the philosophical approach demands integrating different levels of empathic occurrences (cognitive, expressive, bodily, hermeneutic) in a model of empathy, thus claiming empathic capabilities for all human beings. In the final section (6) I will argue that, grounded in resonance and relationality, empathy seems to lend itself to the experiment of linking it to the idea and concept of dividuality.

\section{Point of departure: understanding suffering and pain in the 'anthropology of violence'}

Anthropology of violence as a distinctive area of research is strongly connected with the name of Veena Das, anthropologist and sociologist from India, now based in the United States. ${ }^{4}$ Already by the late 1980s and early 1990s she had laid the theoretical foundations for the new anthropological approach to understanding violence, suffering and pain as a social phenomenon (Das 1987; 1990; 1995). ${ }^{5}$

Violence is perceived as meaningful social action that cannot be reduced to its instrumental aspect; it equally contains expressive and symbolic dimensions, which even may marginalise instrumentality. For Das such a perspective presupposes a particular understanding of the human body, which has to be considered as space or territory for expressive and symbolic action. The body as territory can also function as memory through the inscription of pain - an insight gained from the works of Pierre Clastres and Friedrich Nietzsche. Clastres refers to rites-de-passage in so-called primitive societies. Here social membership is inscribed upon the

\footnotetext{
4 In the United States, Veena Das (Johns Hopkins University, Baltimore) started collaborating with scholars from the disciplines of social medicine, psychiatry and medical anthropology (among others Arthur Kleinmann, Harvard University, USA; Margaret Lock, McGill University, Canada). A number of seminal publications established the anthropology of violence as an internationally acknowledged field of research.

5 The field of anthropology of violence focuses on the social aspects of human suffering. They understand what they call 'social suffering' as 'an assemblage of human problems that have their origins and consequences in the devastating injuries that social force inflicts on human experience. Social suffering results from what political, economic, and institutional power does to people, and, reciprocally, from how these forms of power themselves influence responses to social problems' (Das, Kleinman, Lock 1996, XI). Authors focus, for example, on the Holocaust, the Bhopal gas tragedy, the Indian Partition, South African Apartheid.
} 
body through torture and pain - the price of belonging - and the wounds left on the body preclude forgetting. But whereas for Clastres the ritual equalises all participants as members in a moral community, Nietzsche sees the relation between society and the individual as analogous to that of creditor and debtor. Sociality is based on a contract made by the debtor with the creditor, and in case the debtor would fail to repay, he pledges to submit something that he possesses - his body, wife, freedom or even his life. Here, infliction of pain on a person is seen as legitimate, if this person has caused injury by failing in his obligation; and the infliction of pain creates memory, which is directed to the future. Following Clastres' and Nietzsche's interpretation, Das' research on violent acts (rape, abduction and even murder) against women during the Partition riots, which accompanied the foundation of the states of India and Pakistan in 1947, evokes the bodies of women - in the context of gendered ideologies - as being territory and memory, and thus functioning as 'signs on which the violent dialogue of men was conducted' (Das 1995, 186).

In contrast to sociological research on violence, which tended to objectify and victimise the affected persons, and which 'privatised' their suffering and thus denied them the ability to communicate pain, the new anthropological approach attempted to give space to the 'voice' of the people concerned. ${ }^{6}$ Here it is the anthropologist (the researcher) who takes the role of a witness and a listener, and by accepting the subject in the role of the speaker, establishes a dialogic relationship. After the riots which followed the assassination of Indira Gandhi in Delhi in 1984, a group of anthropologists and sociologists decided to engage in rehabilitation work. They concentrated not only on material help but tried to create a moral space for the expression of grief, guilt, pain, and mourning. The researchers argued that the women and children of males who were killed in the riots had a great need to tell their stories again and again. This is captured in a phrase uttered by one of the women and used by Das as a heading of one of her articles: 'It is our work to cry and your work to listen' (Das 1990).

The need to establish a culture of listening and a therapeutic space in the context of research on violence prompted the involved scholars to reflect on the problem of the communicability and the inalienability of pain. Relating to Ludwig Wittgenstein and his so-called private language argument, ${ }^{7}$ Veena Das formulates two central questions:

\footnotetext{
6 Research on violence in German sociology in the 1990s can serve as an example; see the volume Soziologie der Gewalt (1997), here especially the contributions of Trutz von Trotha, Birgitta Nedelmann, Wolfgang Sofsky.

7 Das refers especially to Wittgenstein's Blue and Brown Books (German ed. 1984) and his Philosophical Investigations (1958). For reflections on the private language argument see e.g. Schroeder 1998; 2007.
} 
When we talk about the communicability of pain, we ask whether it is possible to communicate one's experience of pain to another person. In other words, is knowledge of private objects such as pain only possible for the individual subject, or is it communicable? The second question, about the inalienability of pain, is to ask what it means to "have" a pain.

(Das 1995, 194)

With Wittgenstein she then argues that the statement 'I am in pain' is not simply declarative or descriptive of a purely personal experience (sensation), but it is a (moral) complaint and an invitation to share. It addresses other persons and therefore marks not the end, but the beginning of a language game.

While it seems that pain is communicable, it might still be inalienable. Are my pains only those which are felt in my body or can I feel pain in the body of others? Veena Das extrapolates from Wittgenstein's texts that, at the level of philosophical grammar, he denies an individual ownership in pain: my pains are those to which I give expression, and a person's expression (of pain) may indicate that the pain is located outside his or her body:

In order to see that it is conceivable that one person should have pain in another person's body, one must examine what sorts of facts we call criteria for a pain being in a certain place. [...] Suppose I feel a pain which on the evidence of the pain alone, e.g., with closed eyes, I should call a pain in my left hand. Someone asks me to touch the painful spot with my right hand. I do so and looking round perceive that I am touching my neighbour's hand.

(Wittgenstein 1958, 49; quoted in Das 1995, 195)

Veena Das emphasises that Wittgenstein's 'brilliant formulation that my pain may be located in another's body, and that the pain of the other may be experienced in my body' indicates that there is 'no individual ownership in pain' (Das 1995, 195). The possibility of sharing pain has a clear moral significance as it allows generating compassion and concern. It also may generate the wish to ease the other person's suffering and thus create a therapeutic space. Das invokes Drew Leder, an American philosopher, who demands 'forming one body' with the sufferer:

[...] one-body-compassion for my sick friend leads me to do what I can for her: hold her hand, offer words of comfort, bring her food, fix her bedclothes. I give over my motoric possibilities to be guided by her desires. If she is thirsty, my hands fetch her drink. If she is weak, my limbs supply her strength. We act as if we were one functioning body, her "I can" supplemented by my abilities, her wishes fulfilled by my work.

(Leder 1990, 163; quoted in Das 1995, 195)

A central concern of the anthropologists following the new approach to understanding violence and suffering is 'healing'. Drew Leder hints at the importance of healing when he states that lending one's abilities to the sufferer means also to bring relief to this person. Suffering, he says, 'is the experience of isolation', it 'disrupts communion with the natural and the social world' and thus the 
one-body experience can act as a healing force (Leder 1990, 161). Listening to narratives of violence, lending one's body to those in pain, all this might allow the affected person(s) to heal, to become able to get back to ordinary life. Though the ordinary will always remain imbued by the memory of the severe disruptions that happened, 'descent into everyday life' (Das 2007, 15) seems to be the only way of repairing and 'remaking a world' after trauma. ${ }^{8}$

The anthropology of violence emphasises the possibility of communicating and sharing pain even under conditions of deep social disruption, and stresses the healing force of both. It thus reveals a particular social and moral quality of the human being, namely empathy: the emotional capability to feel with the other, to get marked by (the pain of) the other and even feel compelled to lend (part of) one's body to ease this pain. Empathy apparently presupposes vulnerability and thus a porous, partible body-mind entity. At this point it seems fruitful to relate the anthropological discussion with the broader cross-disciplinary debate on empathy, ${ }^{9}$ which has proliferated in recent decades in the disciplines of history, philosophy, social and cognitive sciences.

\section{Human suffering and the birth of fellow feeling}

While human emotions are anchored in the biological nature of human beings, the way emotions are realised and socially evaluated, and are the subject of language and reflection, is dependent on time and cultural context. The cultural grammar of emotions as well as theories of emotions are historically contingent (Frevert, 2014; Wilkinson, Kleinman 2016). On this assumption, any statement about empathy - here understood as the emotional competence to relate to the suffering of others - needs to be historically located and contextualised. First and foremost one has to take into consideration that there might be variations in the way people relate to and comprehend human suffering in the course of history. For the purpose of this paper I want to relate to the already referenced study of Wilkinson and Kleinman and, following their analysis of relevant scholarly work from the Western context, ${ }^{10}$ briefly inquire about the socio-historical circumstances

\footnotetext{
8 See the title of a publication edited by Veena Das and others (2001).

9 Empathy refers to the Greek word pathos, which means to suffer, to endure. The word is a neologism invented by E. B. Titchener in 1909; he used 'empathy' to translate the German word Einfühlung, common in the German-speaking world in hermeneutics, aesthetics and psychology. 10 I am aware that in other cultural and religious contexts the meaning of suffering, the role of emotions and empathy have been and are differently interpreted.
} 
under which the meaning of human suffering becomes interpreted as an explicitly social condition, which demands moral commitment and prompts empathy. This is to ask about the origins and dynamics of 'moral individualism', that is the disposition to show pity and sympathise with those who suffer (Wilkinson, Kleinman 2016, 26f.). ${ }^{11}$

Understanding human suffering in social terms presupposes a radical shift in the relation between human beings and the transcendental (or god). It requires, so Wilkinson and Kleinman, a departure from a theological interpretation. In the European Middle Ages and early modernity, devoted to the tradition of Christianity, a consensus about the cause and meaning of human suffering prevailed. Suffering was often understood as sent by God, not only as punishment for wrongdoing but also to redeem his creation from sin. Hardship and pain, which people experienced in various forms, like earthquakes, floods, famine, and diseases, was invested with moral and divine meaning. Especially in Protestant cultures, with their emphasis on predestination and attainment of salvation solely through God's grace, the 'doctrines of Providence' had the greatest impact on public and personal affairs. The belief in the rightness of God's judgement, the meaningfulness of his signs, was highest in the 16th and 17th centuries; and it went along with an impulse in the direction of individualisation. In order to rightly interpret and understand God's ways, each individual had 'to examine his conscience, motivations, and actions in light of biblical teachings on the means to [...] salvation' (ibid., 32).

In the second half of the 17th century, providentialism increasingly lost its explanatory power. Intellectuals and educated circles, upwardly mobile groups and political movements worked against what they considered superstition and irrational belief. Also amongst lower classes scepticism about the promises of reward in the next world for patiently enduring the evils of the present was not unusual. Wilkinson and Kleinman support this argument by invoking the scholarly works of Ann Thompson (2003) and Jennifer Herdt (2001). Thompson, who has analysed sermons and Christian writings from the 17th century, argues that the post-Reformation (Puritan) way of interpreting suffering was replaced by the conviction that God's ways are beyond understanding. Herdt concludes from her research, on Cambridge Platonist Ralph Cudworth and his influence on other Latitudinarians (17th century English theologians from the University of Cambridge), that new theological emphasis is laid on the idea that God feels with those in pain

11 Other scholars have also attempted to trace the history of empathy, for example Jeremy Rifkin (2009), who gives a sweeping account about empathy in the world's civilisations up until today, and Lynn Hunt (2007), who traces empathy as a precondition for the invention of human rights. 
and suffers along with them. In the figure of Christ as the incarnated God, the creator himself relates to human beings with compassion, and in consequence God is seen as more responsive to, but less responsible for human suffering. Herdt further argues that the work of the Latitudinarians marked a transitional phase in European intellectual history. Divine passibility (God's capability to respond emotionally to his creation) promoted secularising tendencies within sentimentalist ethics in the culture of Enlightenment. It was the philosopher Francis Hutcheson (1694-1746) who was the first to take up the humanitarian interpretation of Christianity and advance the idea that human beings are distinguished by a God-given 'moral sense', and thus by the capacity for a morally grounded sentiment of fellow feeling.

By the end of the early 19th century the attitude towards human suffering had undergone a radical transformation. Suffering had become increasingly morally unacceptable and was criticised as something that has a mundane, secular cause. Social circumstances, conditional for these causes, could and should be changed. People responded to public execution of punishment with disgust and started campaigning against such spectacles (Hunt 2007). In literature and theatre, sentimental novels and plays proliferated and the audience celebrated their shared humanity (Hunt 2007; Mullan 1988). While the new sensibilities and manifestations of compassion were de facto recent or 'modern' phenomena, they were considered as expressions of 'natural instinct' (Wilkinson, Kleinman 2016, 39). In their capacity as natural moral feelings they enabled a new imaginary of sociality and moral conduct.

Two main reasons seem to account for the cultural constitution of the compassionate orientation of human beings in the 18th and 19th centuries (ibid., 43f.): the process of civilisation (as outlined, eg., by Norbert Elias), and/or experiences of individualisation in the wake of the emerging capitalist economy. In the first case, compassion is seen as a by-product of internalised self-restraint and sublimation; in the second, it is assumed that the involvement of individualised people in market relations created new bonds and moral responsibilities. Capitalist market structures also are considered seminal for the emergence of a new middle class for which sentimentalism became a form of mass entertainment. The demand for 'partaking in the pleasure of tears' led to a 'cultural manufacture of fellow-feeling' and also laid the foundation for a profitable business (ibid, 44).

In order to sum up the transformation of European ideas on human suffering since the Christian Middle Ages, which are interlinked with changes in emotional conditions, we have to highlight three aspects: (1) a shift from a theological to a secular interpretation of the causes of suffering; (2) recognition that the conditions of life are a result of human praxis and therefore subject to change; (3) an ongoing trend to individualisation and the acceptance of social and moral 
responsibility for fellow human beings, expressed in a compassionate relationship to the other. To put it in the words of Wilkinson and Kleinman:

Social life is emphatically portrayed as moral experience; and it is further assumed that by moral feeling we stand to acquire a vital part of our knowledge of society. On these grounds, it is widely accepted that social dispositions are manifested in the moral outrage experienced in the face of human suffering and then when touched by the miseries of others we are made consciously alert to social bonds. At its origins, the critical impulse that brings debate to the human social condition as such is allied to the conviction that social life is animated by our capacity to sympathize morally with the suffering of others.

(ibid., 46; second accentuation AL)

\section{Sympathetic imagination as social and moral force}

Two eminent thinkers of the 18th century Scottish Enlightenment, David Hume (1711-1776) and Adam Smith (1723-1790), elaborately reflect on the moral sentiment of co-feeling as constitutive for sociality. ${ }^{12}$ In the centre of these reflections is the notion of 'sympathy'.

In his main work, A Treatise of Human Nature, David Hume challenges the priority of reason as a motive for social action and gives passions a prominent place in considerations about the human constitution and human society. Passions (or sentiment, feelings) are not expressions of private desires or interests, they are rather directed towards fellow human beings and 'are so contagious, that they pass with the greatest facility from one person to another, and produce correspondent movements in all human breasts' (Hume 2001, 386). Passions advance communication among fellow human beings; the movement of passions, however, is enabled by 'sympathy', a 'remarkable' quality of human nature, both in itself and in its consequences (ibid., 206).

Interpreters of David Hume's work emphasise that he understands sympathy as 'a psychological mechanism that explains how we come to feel what others are feeling. It is not itself a feeling or sentiment [...]' (Morris, Brown 2014, section 7.2). The mechanism of sympathy brings a person from the 'idea of what someone is feeling to actually experiencing the feeling' (ibid.); and for that four steps are needed: first, to have an idea of the other's feeling; second, to become aware of the resemblance, the associative relation between me and the other (including

12 For the reception on Hume and Smith I refer primarily to Mullan (1988), Haakonssen (2002), Morris and Brown (2014), Agosta, undated). 
the awareness that I feel closer to those who are near to me in time, space, and through family relationships); third, to become aware of myself; and finally, the perception of the other is transmitted by force and vivacity to my perception. Hume summarises: '[...] sympathy [...] is nothing but the conversion of an idea into an impression by the force of imagination' (Hume 2001, 273; emphasis AL).

Adam Smith integrates the theory of imagination, developed by Hume, as a central element of his work on moral sentiments. For Hume and for Smith, so Knud Haakonssen, the imagination is a mental faculty, which spontaneously searches for order, coherence and agreement in the world and so enables people to 'create a distinctively human sphere within the natural world' (Haakonssen 2002, xii). Haakonssen distinguishes two forms of imagination in Smith's work: 'theoretical' imagination, directed towards things and events, and 'practical' imagination, concerned with persons as agents. This latter form of imagination is what Smith calls sympathy and what he considers crucial for human morality. It is a mechanism or process to reach out to other people, to understand the other's point of view and prepare moral assessments - it is not the assessment itself. ${ }^{13}$ Smith describes this process vividly:

As we have no immediate experience of what other men feel, we can form no idea of the manner in which they are affected, but by conceiving what we ourselves should feel in the like situation. Though our brother is upon the rack, as long as we ourselves are at our ease, our senses will never inform us of what he suffers. They never did, and never can, carry us beyond our own person, and it is by the imagination only that we can form any conception of what are his sensations. [...] It is the impressions of our own senses only, not those of his, which our imaginations copy. By the imagination we place ourselves in his situation, we conceive ourselves enduring all the same torments, we enter as it were into his body, and become in some measure the same person with him, and thence form some idea of his sensations, and even feel something which, though weaker in degree, is not altogether unlike them. His agonies, when they are thus brought home to ourselves, when we have thus adopted and made them our own, begin at last to affect us, and we then tremble and shudder at the thought of what he feels. For as to be in pain or distress of any kind excites the most excessive sorrow, so to conceive or to imagine that we are in it, excites some degree of the same emotion [...].

(Smith 2002, 11f.)

Through sympathy as an act of imagination a person comes to understand other people's feelings. However, this is for Smith a mutual process, because in the same way as the other as a moral being is a creation of 'my' imagination, I am as

13 'Pity and compassion are words appropriated to signify our fellow-feeling with the sorrow of others. Sympathy, though its meaning was, perhaps, originally the same, may now, however, without much impropriety, be made use of to denote our fellow-feeling with any passion whatever' (Smith 2002, 13). Smith, however, is not always consistent in his use of the term and sometimes seems to use sympathy as synonymous with compassion. 
well an act of 'his/her' imagination. Moreover, in this act of imagination lies an even greater significance: while people interact, they learn to see their own sentiments and feelings with the eyes of others:

The central point is that we only become aware of ourselves [...] through our relationship to others. When we observe others, we notice that they observe us, and one of the most urgently felt needs for sympathetic understanding is to appreciate how they see us. [...] Our understanding of how others see us [...] shapes our view of who we are and how we stand in [...] relationships in life.

(Haakonssen 2002, xv)

Haakonssen is convinced that Adam Smith was very much aware of the fact that the human being in its personal and moral existence is constituted by social relationships and mutual interaction with (significant) others: '[...] one only learns to see oneself as a person and as a member of a moral universe of agents through sympathy with other's view of one's identity and situation in the world' (ibid.). ${ }^{14}$ Human beings are social beings and they can only act in the world on the basis of sympathetically imagining the others' expectations: persons anticipate the assessment of themselves by others and adjust their own behaviour in a social setting according to the need of agreement or conformity, or to avoid conflict. With that, human social beings 'internalize the external spectator and respond to this figure of the sympathetic imagination' (ibid.).

Besides grounding social life in interaction, Adam Smith also lays the foundation for a social rationale of morality, thereby dismissing the idea of a universal morality as well as ascribing it to the authority of conscience and thus finally to God. Like other 'conventions' morality is a result of adaptation to the respective circumstances humans live in and is thus historically and socio-culturally contingent. ${ }^{15}$ To establish the social basis of morality Smith imagines the ideal of an 'impartial spectator', 'the man within the breast' (Smith 2002, 182), who judges (similarly to a third person) without bias and serves as a 'moral compass' (Hunt 2007, 65). This imagination, Haakonssen emphasises, is itself an act of mutual sympathy, as we try to understand the way the ideal impartial spectator - not limited by prejudice, ignorance and so on - would sympathise with us and so appraise us (Haakonssen 2002, xv).

14 The insight that taking the role or the perspective of the other is paramount for the development of the human personality was developed by G. H. Mead and became central for the pragmatist approach to philosophy, sociology and social psychology.

15 Haakonssen argues that setting aside the 'ancient divide over the issue of nature versus artifice in morality' is Smith's most original contribution to moral philosophy. According to Smith artifice is natural to humankind and there is 'no condition in which people do not generate moral, aesthetic and other conventions' (Haakonssen 2002, xii). 
Arguing that the capability of imagining an impartial spectator presupposes involvement in self-reflexive mutual social interaction also means presupposing an autonomous Self. Lynn Hunt puts it bluntly, saying that autonomy ${ }^{16}$ and sympathy go together for Smith (Hunt 2007, 65). Smith's approach to human sentiment and sympathetic imagination therefore qualifies as a pioneering statement about the constitution of morality, sociality and personhood under conditions of modernity.

\section{Sympathy, language and understanding}

The 18th century emphasis on sympathy and the natural sociability of humanity coincides with an emerging interest in language as a main means of communication. ${ }^{17}$ Hans Aarsleff (2006) gives an account of the main debates in the philosophy of language in the 17th and 18th centuries and reconstructs the 'rise of rhetorical expressivism' - the development from a cognitive to an emotive theory of meaning. Aarsleff emphasises the innovative shift that happened in the 18th century: for the first time language was seen as a basic social institution and, as a historical phenomenon, was analysed in historical terms. ${ }^{18}$ Aarsleff considers the work of Etienne Bonnot de Condillac, especially the Essai sur l'origines des connaissances humaines (1746), as pivotal for the understanding of speech and knowledge as 'aspects of our natural history'. Condillac's significant contribution lies in two main arguments: against the Cartesian view that knowledge originates in the mental life of a silent, isolated individual, he claims that meaning arises in dialogue, and discursivity as a condition of knowledge is a function of public speech. He further argues that language owes its origin to 'a combination of instinctually affective communication and reflectively conceived artificial signs ${ }^{19}$ (Aarsleff 2006, 451). Condillac thus established the idea that language, as

16 Autonomy in this context refers to an ontogenetically fully developed, morally accountable, self-reflexive person (in the sense of Lawrence Kohlberg's post-conventional morality), and not a de-contextualised, a-social and self-contained individual, assuming him/herself as a privileged locus of action and reason.

17 I thank Knud Haakonssen for having drawn my attention to reflections on language in the 17 th and 18th century and their relevance for the discussion on empathy.

18 See Haakonssen 2016; Haakonssen has edited a volume honouring Hans Aarsleff and his seminal work on language as part of a contextualist intellectual history.

19 Condorcet differentiates between accidental signs (signs that trigger an unexpected recall), natural signs (cries that nature has established for the sentiments of joy, fear, pain etc.), and instituted signs (those we ourselves have chosen; they have an arbitrary relation to our ideas); see Aarsleff 2006, 460. 
a system of signs, cannot be private, but results from social intercourse, and the 'language of action' (emotive expressions, natural sociability and sympathy) provides a proto-language. For Condillac, so Aarsleff, 'the essence of humanity is the activity of the mind that is generated when thinking is cycled into action by signs and their use in dialogue. Without language, there is no humanity' (ibid., 463f.).

Aarsleff makes a valid argument by indicating the similarities between the work of Condillac and that of the later Wittgenstein. He highlights that both scholars argue against the Descartian dualism of body and mind, oppose the view of language as emerging from the privacy of an individual mind and stress its ultimate grounding in sociality, and they see in action the beginning of language: 'The language of action initiates a game that occurs within a form of life, and, like a game the language of action carries no implication that it is guided by reason' (ibid., 468).

The analogy between Wittgenstein's theory of language and that of 18th century scholars leads me back to the anthropology of violence and the reflections on the communicability of pain. Considering the fact that languages come from and still carry some marks from the expressive language of action, already the cry of pain is a sign that addresses somebody and awaits a response. It means moving out of isolation, locating my pain in the body of another person who then experiences my pain in her/his body. The cry of pain is an appeal to the other, a plea to communicate, the beginning of a language game (as mentioned above). The centrality of language as facilitating communication even in suffering, and with that consolidating social bonds and sympathic relationships, has been strongly emphasised by Veena Das, and it is worth quoting her again:

In this movement between bodies, the sentence "I am in pain" becomes the conduit through which I may move out of the inexpressible privacy and suffocation of my pain. [...] Pain in this rendering is not that inexpressible something that destroys communication or marks an exit from one's existence in language. Instead, it makes a claim on the other - asking for acknowledgement that may be given or denied. In either case, it is not a referential statement that is pointing to an inner object.

(Das 2007, 40)

The reflections on the communicability of pain and the centrality of language in this process carry the implicit assumption of understanding not only as a cognitive phenomenon but also as function of experience. The willingness to let the suffering of the other happen to me, capture, take hold of me, means to share the other's pain and - even if not fully - experience the other as somebody in pain. I, as an individual person can experience and so understand the sentiments of another individual, the You, because of our common sociality and linguistic faculty.

In the context of his reception of Condillac's Essai, Denis Diderot presents some further thoughts on the question of the relationship between language and 
individuality. He asks: What happens to individuality in the process of communication? Diderot's answer evokes the poverty and insufficiency of language, which he considers unable to grasp the richness and multitude of personal feelings, and he states that in a successful communication we have to surrender part of our individuality, with the consequence that 'we never precisely understand, we are never precisely understood' (Diderot, in Aarsleff 2006, 471). ${ }^{20}$

Diderot seems to bring forward two different but interrelated arguments: firstly, he addresses the impossibility of fully partaking in the sentiments of another person (because of the richness of the other's personal feelings and the lack of linguistic means to express them) and so points to the limits of communication and understanding. Secondly, he emphasises the limits of individualisation and with that hints at the impossibility of becoming (and being) a totally bounded and in every respect self-sufficient and self-determined subject. Communication (sociality) uncompromisingly requires sacrificing part of one's individuality and so dividing oneself, and at the same time communication (sociality) is never encompassing, absorbing the individual (being much more than what is transmittable in language and communication). It is the dialectics of the relationship between individuality and sociality that is here at stake, historically and culturally contingent and demanding specific research.

The reflections on communication and understanding have an additional dimension: they can throw light on the difference between sympathetic imagination perceived as either based on relationality between individuals, or thought about as identification, or unification. For this purpose we have to turn first to Martin Buber (1970) and then to Karl F. Morrison (1988).

'Man becomes an I through a You' writes Buber (1970, 82), and he explains:

The basic word I-You can be spoken only with one's whole being. The concentration and fusion into a whole being can never be accomplished by me, can never be accomplished without me. I require a You to become; becoming I, I say You. All actual life is encounter.

(ibid., 62)

Buber's message is explicit: without intersubjectivity there is no Self, and only an inter-subjectively constituted relational Self has the capacity for sympathetic imagination and can reach out to others. ${ }^{21}$ In the course of his argument

20 Individuality remains in the way we speak (the accent), but not what (the words, the language) we speak (Aarsleff 2006, 471f.).

21 Dan Zahavi (2012) understands the inter-subjectively constituted or 'interpersonal' Self as the core or minimal self: 'a self, whose self-experience is constitutively dependent upon others, i.e., whose self-experience is mediated through others'. This core self is complemented by the narrative self, thus forming the 'complex Self'. 
it becomes evident that he makes a clear distinction between I and You being in relation, and I and You being in a process or state of unification or identification, which shows itself particularily in religious contexts. Buber opposes religious ideas that either see God as merging into the Self by stripping the latter of all subjectivity (unification), or imagine the Self as the divine, the 'One that thinks and is' (identification). To explain the first case Buber refers to Christian thinking and especially to the works of Meister Eckhart ${ }^{22}$; for the second case he takes examples from Indian religions - the Upanishads and the teachings of Buddha. The problem for Buber is that both forms of religious imagination 'annul relationships' (ibid., 132), ultimately conditional for the formation of the human subject as a separate and 'whole being' and thus for his capability to encounter others.

The historian Karl F. Morrison looks for identification processes - processes where relationships merge into identity - in Western literature, theology and art. His investigation identifies four forms in which processes of assimilation/ identification occur: cosmological, sacramental, metaphysical and epistemological. ${ }^{23}$ The goal of all mimetic processes, so Morrison, was self-extinction - 'to reduce the symmetry of "I" and "you" through stages of diminishing likeness and increasing identity' (Morrison 1988, 32). Morrison argues that the desire to assimilate or identify with a (human or trans-human) counterpart is grounded in the longing to fully understand the other. He therefore introduces the concept of the 'hermeneutic gap' to explain the human desire to move from the symmetric relationship between 'I and You' to the 'I am You'.

While both sympathetic imagination and identification (or unification) go beyond cognitive (spiritual, intellectual) ways of sharing meaning and include bodily and sensual forms of reaching out to the other, they also display a fundamental difference: sympathetic imagination, as a necessary moment in the encounter of relational Selves, gives evidence of the social foundation and the moral potential of the human being. As Leder remarks with reference to Max Scheler, 'to experience true sympathy for others (Mitgefühl), it is necessary to retain a sense of their otherness' (Leder 1990, 162); the moment 'our identities

22 It should be emphasised that Buber's interpretation of Meister Eckhart is not uncontested; see the contribution of Markus Vinzent in Part 2 of this publication.

23 He traces the cosmological identity of God and the world from Vedic to European / Mediterranean text and his examples show the entanglement of thoughts and histories; sacramental communion shows in his opinion for example in ancient mystery cults and Christian sacraments; references to metaphysical unity can be discovered in Greek philosophical ideas about identity of parts and the whole, the continuous process of generation and the immanence of god in the world. Epistemological identification seems to be reflected in likeness between knower and known, lover and beloved, and in theatre and art, between actor and character (impersonation), artist and work, beholder and work. 
blur, I can no longer speak of concernful relation' (ibid.). In contrast, the blurring of identities or total identification seems to marginalise sociality and moral commitment. Instead, it takes into account the desires of the 'I' to complement one's own Self or lose one's Self in order to achieve a state of absorption, an imagined, idealised unity - be it with the divine, the species, or the cosmos. Identification is often based on a feeling of deficit and/or estrangement. It aims at completion or absorption; it aims at one-ness with the other and means the end of sociality, morality and communication.

\section{Empathic occurrences: relationality, resonance, and articulation}

In recent decades, research on empathy proliferated in the fields of biological and cognitive sciences, as well as in social sciences and in philosophy. Especially the neurosciences engage in extensive investigations about the neural correlates of empathy and study brain activities particularly in those brain areas considered relevant for intersubjective performances. ${ }^{24}$ The new insights and explanations about the biologically grounded human capacity for and mechanisms of empathy led Fritz Breithaupt, scholar of cultural studies and cognitive sciences, to the conclusion:

The cognitive sciences not only provide astonishing insights into the mechanisms of empathy, but also show us that people cannot help but empathise with others. Evidently, much of our capacity for understanding one another on an intellectual and emotional level stems from our inherent ability for mimicry, along with fundamental neuronal possibilities that allow us to experience the observed behaviour of others as our own actions.

(Breithaupt 2009, 8; transl. AL) ${ }^{25}$

24 Research on the empathic capacity of humans is located within the wider field of the search for 'neural correlates of consciousness', which tries to understand the 'nexus between the virtuality of an external existence and the internal dynamics of biological information-processing' (Metzinger 2000, 3). For an overview see the compilation of Metzinger (2000); for neuroscientific and medical research regarding empathy see Watt and Panksepp 2016; Hein 2011; 2016. Primatologist Frans de Waal (2012) traces the evolutionary history of empathy by discussing research on empathy among animals, especially monkeys and apes; a controversial debate developed around the discovery of mirror neurons, labelled as 'the most hyped concept in neuroscience' (Kilner, Lemon 2013).

25 'Die Kognitionswissenschaften geben uns nicht nur erstaunliche Aufschlüsse über die Mechanismen von Empathie, sondern zeigen auch, dass Menschen wohl gar nicht anders können als mit anderen mitzufühlen. Die Fähigkeit des intellektuellen und emotionalen Verstehens von 
In line with this argument, Douglas Watt and Jaak Panksepp (2016) analyse a range of definitions of empathy and identify three basic components in all of them: 'feeling what someone is feeling' (affective resonance/contagion); 'knowing what someone is feeling'; and 'having some intent to mitigate suffering' (Watt, Panksepp 2016, 11). Empathy, which they define as a 'prosocial process essential for the mitigation of suffering' (ibid., 3) thus refers to affective as well as to higher cognitive processes and indicates the human capacity for moral concern.

While approaches from cognitive sciences so far seem to focus on the affective and cognitive capacity developed by and existing in an (isolated) individual human being (who only in a second step enters into a relationship and reaches out to fellow human beings), philosophical approaches influenced by pragmatism start from the assumption that the cognitive capacities of an individual are already intersubjectively constituted. Thiemo Breyer (2015) presents an elaborate attempt in this regard and discusses empathy from a philosophical-anthropological-phenomenological perspective, building on a basic and necessary embodiment of human relationships to the world, to others and to oneself.

Breyer starts by criticising approaches from cognitive sciences for being reductionist, as they seem to understand human empathic capacity basically as a result of sub-personal (neuronal) activities or higher cognitive processes. Empathy, so his argument, happens here in the self-contained system of the observer and he pleads for an alternative interpretation, which builds on the paradigm of embodied cognitive science ${ }^{26}$ and the idea that empathy occurs in the open space of bodily encounter and social and linguistic interaction between Self and Other.

Taking the specific manner, in which intentional states are connected in the context of secondary personal episodes of reciprocal reference of I and You as a starting point, one then has to ask the epistemological question regarding the psyche of the stranger the other way

anderen beruht offenbar zu einem nicht unerheblichen Teil auf angeborenen Fähigkeiten zur Mimikri und auf basalen neuronalen Möglichkeiten, die uns das bei anderen beobachtete Verhalten wie das eigene Handeln erleben lassen' (Breithaupt 2009, 8).

26 Breyer refers to the paradigm of $4 E$ Cognition $(2015,30)$. He argues that $4 \mathrm{E}$ Cognition has become the label for philosophical approaches focussing on embodiment. The human mind is, first of all, embodied; in its embodied condition it is also extended, embedded and enactive. Embodied relates to the nexus between cognitive states and the particularities of the body they inhabit. Extended indicate that processes of the mind reach into the sensory system and the motoric functions; senses are not passive receptors of outer influences but are also shaped by cognitive factors. It also points to the instrumental use of auxiliary tools, for example when calculating. Embedded relates to the fact that cognition happens in spacial, instrumental and cultural contexts. Enactive highlights the fact that the human organism creates its world in a process of actively structuring it. 
around: "how am I able to make a meaningful distinction between my own state of mind and being and yours?" This question is different from the one that has usually been asked in the "Theory of Mind," namely "How can I access your states of thought and being from my own outside perspective?".

(Breyer 2015, 47; transl. AL) ${ }^{27}$

Breyer presents a complex model of empathy, which builds on relationality and starts from the realities of an intersubjective encounter (ibid., 48ff.). Empathy thus develops through various levels of empathic occurrences: bodily resonance (leibliche Resonanz), understanding of expressions (Ausdrucksverstehen) and understanding of the alien Other (Fremdverstehen).

The human being is never in a cognitively neutral state, but has always to cope with transitions from one mood to the next. The emotional atmosphere is a medium through which the world appears to human beings and through which they also experience others. However, the atmospheric space of encounter (Begegnungsraum) and the atmospheric conditions are always (already) intersubjectively shaped. It is the human body that functions as soundboard for atmospheric conditions by translating the space-tuned phenomena into self-resonance, ${ }^{28}$ and this elementary capacity to resonate is the precondition of empathy. ${ }^{29}$ Breyer conceptualises a common, an empathic space that is formed by the two partners of an intersubjective encounter:

The other co-designs the empathetic space by allowing me to develop a deeper understanding of his/her circumstances. This means that the other, him/herself, provides me with the supporting structures and elements that give rise to my empathic relationship. Emotions do not linger or erupt in the physical interior of an isolated subject, but reach out into the atmospheric space, which can hold multiple subjects and, thus, enables processes of empathy.

(ibid., 50; transl. AL) ${ }^{30}$

27 'Von der spezifischen Art des Zusammenhangs von intentionalen Zuständen in den zweitpersonalen Episoden der reziproken Verwiesenheit von Ich und Du aus gesehen, stellt sich nämlich die epistemologische Frage nach dem Fremdpsychischen anders herum: "Wie kann ich zwischen meinem und deinen Zuständen überhaupt sinnvoll unterscheiden?” - nicht wie in der Theory of Mind üblich: "Wie komme ich von meiner Perspektive aus an Deine Zustände von außen heran?”' (Breyer 2015, 47).

28 'Der Leib fungiert [...] als Resonanzboden für Stimmungen, indem er "die stimmungsräumlichen Phänomene in seine Eigenresonanz” überträgt' (Breyer 2015, 49).

29 Hartmut Rosa tries to make research on empathy fruitful for his theory of resonance (Rosa 2016, ch. V).

30 'Der Andere gestaltet [...] den empathischen Raum mit, in dem ich ein Verstehen seiner Zustände entwickeln kann, das heißt er selbst stellt unterstützende Elemente für meinen Empathiebezug bereit. Gefühle spielen sich [...] nicht im psychischen Innenraum eines vereinzelten Subjekts ab, sondern greifen in den Stimmungsraum aus, der mehrere Subjekte umfassen und so empathische Prozesse ermöglichen kann' (Breyer 2015, 50). 
From the primary level of bodily resonance, that is allowing oneself to be affected (pathisches Sich-affizieren-Lassen; ibid., 49), one reaches the next level of empathy, where the significance of specific expressions can be understood (Audrucksverstehen). These expressions may be universal (based on instinct and affect; conditions like pain, fear, anger); social (socially shaped according to particular norms; ideas of shame, honour, pride); or cultural (conventionalised forms of bodily communication - like gestures - which require learning processes for understanding). The third level, understanding the alien other (Fremdverstehen), with the basic modi of simulation, inference, and theorisation, requires from the subject the ability of changing perspective and recourse to a pool of acquired knowledge. This form of understanding is directed towards comprehending the specific mental state of the other, its context, or the possible further consequences.

Flexibility of perspectives is an important criterion for higher-level types of imaginative empathy and Breyer identifies two different ways of changing perspective (ibid., 169ff.). The first is egocentric transposition - to try to find out how I would feel in the place of the other; the second - allocentric transposition - is to enter the internal world of the other and try to explore how the other is feeling. However, both forms of change in perspective are limited and do not allow one to really experience the emotional state or the sentiments of the other. Instead of the imaginative empathy (evoked previously by Adam Smith) Breyer introduces interpersonal empathy as an even higher form of empathising: here the other is conceptualised as a person equipped with agency, who is actively involved in the shaping of the empathic situation and its interpretation. The paradigmatic site for such an encounter, in which the limits and possibilities of empathic feeling and understanding are negotiated and communicatively processed, is the dialogue (das Gespräch). Language seems therefore a precondition for higher-level empathic communication.

To underline the significance of the interconnection between the corporeal and the linguistic functions in human interaction, Breyer refers to the pragmatist philosopher Matthias Jung and his integrative anthropology based on the concept of articulation (Artikulation), which he defines as

the basic anthropological fact that people explain their own life circumstances and directions to others by articulating motoric impulses and lived qualities, or in other words, transforming structured schemata of action and syntactically organised chains of symbols [...]. When human beings articulate themselves, they generate meaningful structures by realising specific physical - or in the most fundamental sense physiological - patterns.

(Jung 2009, 12f.; transl. AL) ${ }^{31}$

31 In the German original: 'die anthropologisch basale Tatsache, dass Menschen ihre Lebensvollzüge für sich und andere verständlich machen, indem sie erlebte Qualitäten und motorische Impulse artikulieren, sie also in gegliederte Handlungsabläufe und syntaktisch strukturierte 
Jung's theory of human articulation accentuates the essential role of embodied communication in human existence. Due to its expressivity and the possibility for articulation of meaning the human body is designed for communication. Communication encompasses a continuity of indicative-receptive experience, bodily-physical expression and propositional judgements (see also Breyer 2015, 57ff.). Focussing on the interrelation of body, expressivity and language - or, with other words, of somatics and semantics -, Jung identifies five functions of the body for linguistic (phonetic) articulation (ibid., 59ff.): Facilitating communication (mitteilungsermöglichend) - phonetically, mimically, with gestures; linguistic (sprachlich) - embodied language, speech; para-linguistic (sprachbegleitend) bodily articulations like gestures, mimicry; replacing language/speech (sprachersetzend) - autopoetic function, bodily expressions (cry of pain, blushing); limiting language/speech (sprachbegrenzend) - psychosomatic factors, stuttering.

The foregoing brief discussion of the most recent phenomenological approaches to empathy strongly highlights the nexus between empathy, corporeality, inter-subjectivity and language. Now it is time to ask whether such an approach might influence and probably alter the conception of the (modern) individual.

\section{Empathy, dividuality and the (modern) individual: concluding reflections}

Showing empathy, for example with a person in pain, requires recognition of the other as other, or, with the words of Martha Nussbaum, to be aware 'of one's own qualitative difference from the sufferer' (Nussbaum 2001, 328; cited in Breyer 2015, 208). Breyer concludes that the empathic subject exposes a twofold attention (attentionale Spaltung oder Dopplung), as it focuses on the other as other, while simultaneously being aware of the difference between one's own

Symbolketten transformieren. [...] Wenn Menschen sich artikulieren, erzeugen sie sinnhafte Strukturen, indem sie jeweils bestimmte physische - in den basalen Formen physiologische Muster realisieren' (Jung 2009, 12f.).

Jung claims that his theory of articulation differs substantially from alternative approaches in philosophical anthropology: it emphasises the difference between the human species and other living beings (holism of difference) by simultaneously insisting on evolutionary continuity; it evenly emphasises the intrinsic embodiment of mind (Geist) and its categorical difference to animal intelligence; and it postulates primacy of the sign in contrast to ideas (Gedanken) (ibid., 20). 
experience and that of the other. ${ }^{32}$ Only an autonomous subject, ${ }^{33}$ endowed with affective, cognitive as well as social and moral capacities, is in command of such twofold attention.

It seems plausible to say that empathy presupposes some sort of partibility or divisibility as an importantattribute of theindividual. While I am fullyaware of myself, I can also reach out to the other and let myself be affected or marked by her or him, so that for example the other's pain can be located in my body and so can wound me. Empathy also means vulnerability, it signifies the fragility of individual boundaries and thus a certain porosity or permeability of the Self. Such an understanding of the Self may help to give a more precise account of the nexus between empathy, corporeality, inter-subjectivity and language: empathic relations are, firstly, mediated by a space of encounter, in which porous beings, on the one hand, express themselves by emitting expressive and semantic signs (emotions, feelings, speech, paralinguistic expressions), and, on the other hand, imbibe those of the others. Secondly, communication happens through bodily-physical and linguistic forms of articulation, presupposing an individual, autonomous, but partible and permeable Self (i.e. without rigid boundaries). Thirdly, such communication includes receptivity with regard to others, listening, experiencing and understanding the multiple forms of expression and speech, thus allowing empathic understanding even if language fails. Fourthly, and in the case of suffering and pain, empathy as moral capacity enables mitigating the suffering of others and initiating processes of healing by lending one's body to the other, listening and creating a therapeutic space.

Having moved quite far in questioning the idea of a self-contained, bounded individual, it might be rewarding to explore in which way the concept of dividuality, mentioned at the beginning of this paper, can have some interpretative relevance in the debate on empathy. ${ }^{34}$

32 In German: 'bei der sich das Selbst einmal auf den Anderen als Anderen und einmal auf die Tatsache der Differenz zwischen fremdem und eigenen Erleben richtet' (Breyer 2015, 208).

33 Judith Butler pleads for a notion of autonomy that takes into account the relationality and sociality of human beings. 'Given over from the start to the world of others, it bears their imprint, is formed within the crucible of social life; only later, and with some uncertainty, do I lay claim to my body as my own, if, in fact, I ever do [...]. [I]f I build a notion of "autonomy" on the basis of the denial of this sphere of a primary and unwilled physical proximity with others, then am I denying the social conditions of my embodiment in the name of autonomy?' (Butler 2004, 26). In other words: 'If I am struggling for autonomy, do I not need to be struggling for something else as well, a conception of myself as invariably in community, impressed upon by others, impinging upon them as well, and in ways that are not fully in my control or clearly predictable?' (ibid., 27). See also fn 14 of this paper. 34 I limit myself to basic comments with regard to the concept of dividuality. Dividuality as well as its possible proximity to Charles Taylor's concept of Self is discussed in more detail in the introduction to Part 2 of the publication. 
More recently, the concept of dividuality gained considerable significance in the discipline of anthropology through the work of Marilyn Strathern on gender in Melanesia (1988), although it was earlier introduced into the anthropological discourse by McKim Marriott in his study on Hindu transactions (1976). Strathern wanted to highlight and conceptualise the difference between the (ideal of the) Western individual and her understanding of Melanesian personhood. While in the Western context relations are considered external to the clearly bounded individual, in Melanesia, however, relations are seen as being within, or incorporated in the individual: 'Melanesian persons are as dividually as they are individually conceived' (Strathern 1988,13). Dividuality thus refers to the fact that Melanesian persons are multi-authored and composite beings: they are the product of gifts, divine or human substances; they are 'constituted of the detached parts/relationships of other persons through prior agentive elicitations and exchanges' (Mosko 2010, 215). A singular person (an individual) can be imagined as dividual, or, as Strathern frames it, 'as a social microcosmos' (Strathern 1988,13).

The way 'dividuality' is used in the work of Marilyn Strathern has two major shortcomings. First of all, Strathern's conception of dividuality postulates a container idea of the person, in which objects and relations deriving from others are incorporated in the sense of distinct substances and added to the original substances of the person. In contrast, we have to consider these in-fluences not as self-contained substances, but as permeable, merging and mingling with each other and with the existing qualities of a person, thus giving rise to a unique entangled personhood with a distinct agentive potential. Secondly, Marilyn Strathern's approach to conceptualising dividual personhood reproduces a dichotomy between Western and non-Western, modern and pre-modern contexts. Scholars from the same discipline and with the same regional focus question such polarisation. Mark Mosko (2013) argues that people from north Mekeo (PNG) reproduce dividual patterns even in the contemporary (modern) context of local capitalist market economy. He also shows that Christianity - a 'highly significant context of Western culture' - is premised on personal partibility, and he refers to the relations between Christians, and between them and their deity (Mosko 2010). For Edward LiPuma 'all societies encode relational, dividual aspects of personhood', and 'persons emerge precisely from that tension between dividual and individual aspects/relations' (LiPuma 1998, 57). The idea of dividuality thus transcends the anthropological context and can help us to understand aspects of modern Western personhood as well. Analysis and description of dividuality, and the relation between dividual and individual dimensions of a person, however, must take into consideration the realities of the particular life worlds of human beings and not the imaginaries in which they are grounded. 
To support the idea of the co-existence of dividual and individual aspects of a person it seems useful recalling Charles Taylor's reflections on the Self and his idea of the 'porous' and the 'buffered' Self (Taylor 2007). In the course of human history human beings undergo significant transformations in their relationship to the outer world, but also to the subjective and the social world (see introduction to Part 2 of this publication). Taylor describes persons of the European medieval ages as 'porous', in this way expressing that a person (a Self) is vulnerable, open to spirits, demons, and cosmic forces (Taylor 2007, 38), which all can and do exert influence. These forces, so Taylor, 'can take us over' (ibid., 34), they can 'penetrate' us (ibid., 35). In contrast, the 'bounded' self of the modern, contemporary Western world has built a boundary between the inner and outer worlds, between human mind/human agency and objects or things. This boundary is essential, it works as a buffer, 'such that the things beyond don't need "to get to me" [...]' (ibid., 38), and the Self can see itself as largely invulnerable. Yet, while Taylor seems to be convinced of the effectiveness of the inner-outer boundary under modern conditions, he has to admit that even the modern buffered individual has porous internal spaces in which sociality and emotions can take root.

For a more adequate conceptualisation of the Self (of personhood) in historical perspective, which takes into account the interdependence of dividual and individual aspects, one has to push Taylor's approach a bit further. Charles Taylor constructs the porous and the buffered self as a dichotomy, representing historical stages of selfhood within the Western world (enchanted vs. disenchanted, engaged vs. disengaged). It is precisely this dichotomy which one has to put into question, not only in the light of the phenomenon of social relationality and empathy, but also in the light of contemporary forms of relating to the outer world, like spiritual embodiment, Christian self-sacrifice or the reception of art work (as discussed in the contributions of A. Malik, Ch. Dureau and J. Vincent in this publication).

In this article I have argued that the empathic subject can take on the suffering and pain of others; it is partible and vulnerable, its boundaries are fuzzy, permeable or porous. This means that in the reality of life, even under conditions of modernity and despite the dominant imaginary of the self-contained individual, dividual aspects or qualities are important features of the Self, of the person as a social, moral being. I therefore suggest understanding porousness and boundedness as qualitative markers on a socio-historical scale or continuum, which takes into consideration social realities as well as ideological constructions of personhood. Persons are never only porous dividuals, nor unambiguously buffered individuals, they neither dissolve in the social nor are they immune against social relationships. The idea of a scale or continuum would allow not only acknowledging the co-existence of relational/dividual and individual aspects of the human 
Self in society, but notably engaging in socio-historical studies of their relation in theory and praxis. We need to explore ideas and realities of permeability and partibility on the one hand, of closeness and boundedness on the other, in particular historical constellations, socio-cultural contexts and situations.

The example of empathic relationships towards the suffering subject illustrates that a human being - from its beginning relationally and communicatively constituted - is a partible and permeable being - vulnerable, marked by and receptive to the suffering of other. Even in the social fabric of modern societies, a social subject encounters areas of life in which openness and permeability is desirable and empathy or emotional competence are counteracting processes of unleashed individualisation. This is however not to deny that a society consists of multiple other areas in which a person must act and behave in a more self-contained way. ${ }^{35}$ In sum: for a human subject to lead a successful social life in a particular socio-cultural and historical context and to act according to situational challenges, it has to be partible and permeable (porous), but it must also have the ability of containment (boundedness). A social subject needs to be dividual and individual, or better, it has to be an In/Dividual.

\section{References}

Aarsleff, Hans. 2006. 'Philosophy of Language.' In The Cambridge History of EighteenthCentury Philosophy, vol. I, ed. K. Haakonssen, Cambridge: Cambridge University Press. 451-95.

Agosta, Lou. Undated. 'Empathy and Sympathy in Ethics.' In Internet Encyclopaedia of Philosophy: A Peer-Reviewed Academic Resource,

http://www.iep.utm.edu/emp-symp (last access April 14,2018).

Breithaupt, Fritz. 2009. Kulturen der Empathie. Frankfurt a.M.: Suhrkamp.

Breyer, Thiemo. 2015. Verkörperte Intersubjektivität und Empathie: Philosophischanthropologische Untersuchungen. Frankfurt a.M.: Vittorio Klostermann.

Buber, Martin. 1970. I and Thou. A new translation, with a prologue and notes by Walter Kaufmann. New York et al.: Simon and Schuster.

Butler, Judith. 2004. Precarious Life: The Powers of Mourning and Violence. London/New York: Verso.

Das, Veena. 1987. 'Anthropology of Violence and the Speech of Victims', Anthropology Today 3.4. 11-3.

Das, Veena (ed.). 1990. Mirrors of Violence: Communities, Riots and Survivors in South Asia. Delhi: Oxford University Press.

35 The two main works of Adam Smith, the Moral Sentiments and the Wealth of Nations, can be read as explorations in the partibility of the subject. 
Das, Veena. 1995. Critical Events: An Anthropological Perspective on Contemporary India. Delhi: Oxford University Press.

Das, Veena. 2007. Life and Words: Violence and the Descent into the Ordinary. Foreword by Stanley Cavell. Berkeley: University of California Press.

Das, Veena; Kleinman, Arthur; Lock, Margaret. 1996. 'Introduction', Daedalus 125.1 (Special Volume: Social Suffering).

Das, Veena et al. (eds.). 2001. Remaking a World: Violence, Social Suffering, and Recovery. Berkeley: University of California Press.

Frevert, Ute et al. 2014. Emotional Lexicons: Continuity and Change in the Vocabulary of Feeling 1700-2000. Oxford: Oxford University Press.

Haakonssen, Knud. 2002. 'Introduction.' In Adam Smith: The Theory of Moral Sentiments, ed. K. Haakonssen, Cambridge: Cambridge University Press. vii-xxiv.

Haakonssen, Knud. 2016. 'The Work of Hans Aaarsleff: A Brief Introduction', History of European Ideas 42.6. 724-8.

Hein, Grit et al. 2011. 'Skin Conductance Response to the Pain of Others Predicts Later Costly Helping', PLoS One 6.8.1-6.

Hein, Grit et al. 2016. 'The Brain's Functional Network Architecture Reveals Human Motives', Science 351.6277. 1074-8.

Herdt, Jennifer A. 2001. 'The Rise of Sympathy and the Question of Divine Suffering', Journal of Religious Ethics 29.3. 367-99.

Hume, David. 2001 [repr. with corrections]. A Treatise of Human Nature. Eds. D. Fate Norton, M. J. Norton. Oxford: Oxford University Press.

Hunt, Lynn. 2007. Inventing Human Rights: A History. New York/London: W. W. Norton \& Company. Jung, Matthias. 2009. Der bewusste Ausdruck: Anthropologie der Artikulation. Berlin/New York: Walter de Gruyter.

Kilner, J. M.; Lemon, R. N. 2013. 'What We Know Currently about Mirror Neurons', Current Biology 23. R1057-R1062.

LiPuma, Edward. 1998. 'Modernity and Forms of Personhood in Melanesia.' In Bodies and Persons: Comparative Perspectives from Africa and Melanesia, eds. M. Lambek, A. Strathern, Cambridge: Cambridge University Press. 53-79.

Landweer, Hilge; Renz, Ursula (eds.). 2008. Klassische Emotionstheorien: Von Platon bis Wittgenstein. Berlin/New York: Walter de Gruyter.

Leder, Drew. 1990. The Absent Body. Chicago/London: The University of Chicago Press.

Marriott, McKim. 1976. 'Hindu Transactions: Diversity without Dualism.' In Transaction and Meaning: Directions in the Anthropology of Exchange and Symbolic Behavior, ed.

B. Kapferer, Philadelphia: Institute for the Study of Human Issues. 109-42.

Metzinger, Thomas (ed.). 2000. Neural Correlates of Consciousness: Empirical and Conceptual Questions. Cambridge, Mass./London: MIT Press.

Morris, William Edward; Brown, Charlotte R. 2014. 'David Hume.' In Stanford Encyclopedia of Philosophy, https://plato.stanford.edu/entries/hume (last access April,14, 2018).

Morrison, Karl F. 1988. 'I am You': The Hermeneutics of Empathy in Western Literature, Theology and Art. Princeton, NJ: Princeton University Press.

Mosko, Mark. 2010. 'Partible Penitents: Dividual Personhood and Christian Practice in Melanesia and the West', Journal of the Royal Anthropological Institute (N. S.) 16. 215-40. 
Mosko, Mark. 2013. 'Dividuals, Individuals, or Possessive Individuals? Recent Transformations of North Mekeo Commoditization, Personhood, and Sociality.' In Engaging with

Capitalism: Cases from Oceania, eds. F. McCormack, K. Barclay, Bingley: Emerald. 167-98.

Mullan, John. 1988. Sentiment and Sociability: The Language of Feeling in the 18th Century. Oxford: Clarendon Press.

Nussbaum, Martha. 2001. Upheavals of Thought: The Intelligence of Emotions. Cambridge: Cambridge Universiy Press.

Raunig, Gerald. 2015. Dividuum. Mechanischer Kapitalismus und molekulare Revolution (vol. 1). Wien: transversal texts.

Rifkin, Jeremy. 2009. The Empathic Civilization: The Race to Global Consciousness in a World in Crisis. Cambridge: Polity.

Rosa, Hartmut. 2016. Resonanz: Eine Soziologie der Weltbeziehungen. Frankfurt a.M.: Suhrkamp.

Rüpke, Jörg, 2015. 'Religious Agency, Identity, and Communication: Reflections on History and Theory of Religions', Religion 45.3. 344-66.

Schroeder, Severin. 1998. Das Privatsprachen-Argument: Wittgenstein über Empfindung und Ausdruck. Paderborn et al: Ferdinand Schöningh.

Schroeder, Severin. 2007. Wittgenstein lessen: Ein Kommentar zu ausgewählten Passagen der Philosophischen Untersuchungen. Stuttgart/Bad Cannstatt: Frommann-Holzboog Verlag.

Schwenck, Christiana et al. 2011. 'Kognitive und emotionale Empathie bei Kindern und Jugendlichen mit ADHS und Störung des Sozialverhaltens', Zeitschrift für Kinder- und Jugendpsychiatrie und Psychotherapie 39.4. 265-76.

Smith, Adam. 2002. The Theory of Moral Sentiments (ed. K. Haakonssen). Cambridge: Cambridge University Press.

Strathern, Marilyn. 1988. The Gender of the Gift. Berkeley et al.: University of California Press. Taylor, Charles. 2007. A Secular Age. Cambridge Mass.: Belknap Press of Harvard Univ. Press. Thompson, Ann. 2003. The Art of Suffering and the Impact of Seventeenth-Century Anti-Providential Thought. Aldeshot: Ashgate.

Trotha, Trutz von (ed.). 1997. Soziologie der Gewalt. Opladen: Westdeutscher Verlag.

Waal, Frans de. 2012. The Age of Empathy: Nature's Lessons for a Kinder Society. London: Souvenir.

Watt, Douglas F.; Panksepp, Jaak. 2016. 'Empathy and the Prosocial Brain: Integrating Cognitive and Affective Perspectives in Human and Animal Models of Empathy.' In Psychology and Neurobiology of Empathy, eds. D. F. Watt, J. Panksepp, New York: Nova Biomedical. 3-36.

Wilkinson, lain; Kleinmann, Arthur (eds.). 2016. A Passion for Society: How We Think About Human Suffering. Oakland, Calif.: University of California Press.

Wittgenstein, Ludwig. 1958. Philosophical Investigations. The English Text of the Third Edition. Upper Saddle River, NJ: Prentice Hall.

Wittgenstein, Ludwig. 1969. Das Blaue Buch: Eine Philosophische Betrachtung (Das Braune Buch). Frankfurt a.M.: Suhrkamp.

Zahavi, Dan. 2012. 'The Complex Self: Empirical and Theoretical Perspectives.' In Phenomenology, Cognition, and Neuroscience, eds. J. McCurry, A. Pryor, Pittsburgh: The Simon Silverman Phenomenology Center. 40-58. 